DOI: https://doi.org/10.47405/mjssh.v6i1.620

\begin{tabular}{|c|c|}
\hline$x=$ & Malaysian Journal of Social Sciences and Humanities (MJSSH) \\
\hline Malaysian Journal of & Volume 6, Issue 1, January 2021 \\
\hline (MJ-ssH) & e-ISSN : 2504-8562 \\
\hline & $\begin{array}{l}\text { Journal home page: } \\
\text { www.msocialsciences.com }\end{array}$ \\
\hline
\end{tabular}

\title{
Malaysia: State and Society Measures in Safety and Security Against COVID-19
}

\author{
Atika Shafinaz Nazri 1, Kartini Aboo Talib @ Khalid1, Nidzam Sulaiman', Zaliha Harun² \\ ${ }^{1}$ Institute of Ethnic Studies, National University of Malaysia (UKM) \\ ${ }^{2}$ Faculty of Fisheries and Food Science, Universiti Malaysia Terengganu (UMT) \\ Correspondence: Atika Shafinaz Nazri (atikashafinaz@gmail.com)
}

\begin{abstract}
COVID-19 pandemic is now a global crisis, with the number of known cases climbing has daily and millions of people stranded at home. As countries toil to preserve the lives of their people, economies are grinding to a halt. At this dismal time, Malaysia is facing a vast political crisis with a new leader, and several states have new governments. In this vein, the present study aims at shedding how Malaysian responses to the COVID-19 pandemic on the second wave. This study adopted a qualitative approach that employed secondary data collection from journals, government sector's official websites, NGOs, authorized bodies, and newspapers. Our finding shows that, although Malaysia has COVID-19 during the political crisis, the new ruling party is seen to be competent to manage the issue accordingly with the Ministry of Health and the National Security Council play a vital role in managing the pandemic. The government has taken various measures to ensure the pandemic could be reduced, and economic recession could be minimized that would benefit not only Malaysian but also non-citizens notably to vulnerable with the amalgamate by numerous NGOs.
\end{abstract}

Keywords: COVID-19, economic, government, Malaysia, MCO

\section{Introduction}

At the end of 2019, Malaysia experienced a unique coronavirus (COVID-19) pandemic. At this dismal time, the country is going through a vast political crisis with a new leader, and several states have had new governments. The 14th Malaysian general election (GE14), held on May 9, 2018, had attracted much attention when opposition coalition - the Pakatan Harapan (Alliance of Hope) won and the ruling party - the Barisan Nasional (National Front) step down after 40 years of the ruling (Nadzri, 2019). In an unforeseen turn of events, Mahathir Mohamad had resigned as the Prime Minister after 22 months ruled by submitting a resignation letter on February 24, 2020, to the Yang Di-Pertuan Agong (the King) of Malaysia (Foon, 2020). The latest twist to the weeklong political crisis, on February 29, 2020, Muhyiddin Yasin was appointed as the new prime minister after he has majority support 114 out of the 222 MPs were seated in the government's bloc. The newly formed Perikatan Nasional (National Alliance) government, a coalition comprised of both former ruling and opposition parties, in which Mahathir Mohamad had refused to join due to the presence of United Malays National Organisation's in the coalition (Daim, 2020). In this vein, the present study aims at shedding how Malaysian responses to the COVID-19 pandemic on the second wave. 


\section{Methodology}

This study adopted a qualitative approach employed - secondary data collection from journals, government sector's official websites, NGOs, authorized bodies, and newspapers. The study employed thematic to analyze the data with five phases: familiarising with data, generating initial codes, searching for themes, defining and naming themes and producing the report.

\section{Result and Discussion}

\section{The String of Coronavirus in Malaysia}

The end of the year 2019 has marked the burst out of new pandemic by the deadly virus known as the 2019 novel coronavirus. This virus emerged in Wuhan City, Hubei Province, China allegedly originated from the bat as its reservoir causes the severe acute respiratory syndrome. This virus was later named severe acute respiratory syndrome coronavirus 2 (Adnan et al., 2020). Since the first four cases of the COVID-19 that previously reported as pneumonia of unknown causes on December 29, 2019, this virus has transmitted rapidly worldwide. It led to a massive number of deaths, and millions confirmed cases globally which finally urged the Whole Health Organization (WHO) to declare a pandemic on March 11, 2020 (World Health Organization, 2020).

A first confirmed case in Malaysia was reported on January 25, 2020. It involved a Chinese tourist from Wuhan that travelled to Johor Bharu from Singapore on January 22, 2020. This case had caused a first wave of COVID-19 in Malaysia with a total of 22 positive cases. Nevertheless, all of these cases resolved and discharged well. There were about 11 days following the first wave that reported with zero cases. Unfortunately, the second wave of COVID-19 emerged on February 22, 2020, had surged the confirmed case to 553 positive cases. The second outbreak was related to Tabligh gathering cluster attended by approximately 16,000 people at Sri Petaling from February 27 to March 3, 2020 (Khor et al., 2020).

\section{Government's Policies}

According to the directive No. 20 Policies and Mechanisms in National Disaster Management issued by the National Security Council of the Prime Minister's Department on May 11, 1997, Sub.4: No.6. The incidence of uncontrolled infectious disease/pandemic, as well as disaster resulting from biological accident, is subject to this directive. The Ministry of Health $(\mathrm{MoH})$ is responsible as the Leading Agency to manage outbreaks and disasters due to biological incidence.

\section{a) MovementControl Order (MCO)}

As COVID-19 cases began to rise sharply, the Malaysian Government had imposed movement curbs effectively on March 18, 2020. This drastic immediate action had been made under the Prevention and Control of Infectious Diseases Acts 1988 and the Police Act 1967 to prevent it. Under this MCO, all mass gathering, including religious, sports, social and cultural, were prohibited. Also, to avoid large crowds, the government ordered the closure of premises for worshipping, businesses including all government and private premises. The education sectors were also affected by the MCO in which all of the education centres authorized by the government or private institution commanded to be closed (Malaysian National Security Council, 2020a). The MCO's exception imposed on essential stores such as supermarkets, public markets, and convenience stores selling everyday necessities. Essential services also were allowed during MCO to avoid inconvenience to the people. These included water, electricity, energy, telecommunication, postal, transportation, irrigation, oil, gas, fuel, lubricants, broadcasting, finance, banking, health, pharmacy, fire, prison, port, airport, safety, defence, cleaning, retail, and food supply services (Malaysian National Security Council, 2020b). 
During MCO, all Malaysians had been prohibited from travelling out of Malaysia while all tourists and foreign visitors banned from entering Malaysia. Moreover, Malaysian returning from overseas were required to undergo a health check-up and self-quarantine for 14 days. Law enforcement was endorsed to ensure that everyone abided to the order. Under the Prevention and Control of Infectious Diseases (Measures within the Local Infected Areas) Regulations, 2020 based on a federal gazette that bars individuals from travelling to another place declared as an infected area, those who do not abide the order could be fined not more than RM1,000 or jailed for not more than six months or both (Malaysian National Security Council, 2020c).

The Royal Malaysia Police (RMP) had conducted roadblocks operations dubbed as "Ops COVID-19" along with checkpoints across the country to monitor the people and warned them to abide the order. Started on March 22, 2020, the Malaysian Armed Forces (MAF) mobilized to assist the RMP. This military involvement follows Section 5 of the Prevention and Control of Infectious Diseases Act 1988 (Act 342), which helped the minister authorize any agency deemed necessary to implement the rules imposed (Malaysian National Security Council, 2020d).

\section{b) Conditional Movement Control Order (CMCO)}

While Malaysia's efforts in battling the spread of COVID-19 have proven fruitful, on May 1, 2020, Muhyiddin Yassin has announced a conditional movement control order (CMCO) new norm in facing the COVID-19. Various economic and social activities have been allowed during the CMCO from May 4 until June 9, 2020, subject to the defined conditions and standard operating procedures (SOPs). Restaurants are allowed to operate by observing the business with SOPs, including practising social distancing, recording customer's details (e.g. names and telephone numbers) during their visits (Malaysian National Security Council, 2020e). Nevertheless, the entertainment centres such as cinemas, karaoke, reflexology, night clubs, and theme parks are not allowed to operate and resume their activities. All other shopping carnivals, conferences, and exhibitions are also not allowed. Besides, sports activities, including football, rugby, swimming, and all indoor and stadium sports events involving large gatherings, body contact, and other infection risks are also not permitted. However, outdoor sports activities which did not involve body contact and held in small groups such as badminton or tennis, jogging, cycling, golf and running comprising of not more than ten persons and without the presence of the audience are allowed, providing that the social distancing practised (Malaysian National Security Council, 2020f). Besides, social, community, and cultural events that involve large gatherings such as feasts, open houses, break-of-fast events, concerts, cultural shows, monthly assemblies of government departments, or private sectors, are also not authorized. Religious activities such as religious marches, Friday prayers, and all congregational or assembly activities in mosques and other worship buildings are also not allowed.

In Malaysia, school holidays have begun in the middle of March, while Eid Mubarak festival holidays have specially celebrated by Muslims for few days on started on May 24, 2020. During these two holidays, usually, there were inter-state travels among Malaysians to return to their hometowns that might situate in different states. Thus, inter-state travels are not allowed except for work purposes and returned home after being stranded in the hometowns or elsewhere. Hitherto, all schools, colleges and tertiary institutions are still closed (Malaysian National Security Council, 2020g\&h). Only businesses or activities that had obtained permission from the government could operate, and all employers urged to implement flexible working hours. Employers also advised giving married couples some leeway to work on alternate days, thus helping them solve childcare issues. On the other hand, the public and private sector employees, are encouraged to work from home as part of the measures to prevent congestion of public transportation and public vehicles besides they also need to wear face masks and bring along the hand sanitizers outside the house (Malaysian National Security Council, 2020i). The CMCO termination is unconfirmed and updated from time to time, depending on the development of COVID-19 cases. 
DOI: https://doi.org/10.47405/mjssh.v6i1.620

\section{c) Containmentof Infectious by Quarantine}

Quarantine employed to keep someone who might have been exposed to COVID-19 away from others. Quarantine helps prevent the spread of disease that might occur before a person knows they are sick or infected with the virus without symptoms. Particularly for Malaysian, precautious steps to quarantine different groups of people should follow directions from the state or $\mathrm{MoH}$.

\section{d) Malaysians returning from abroad}

In collaboration with the Embassy of Malaysia abroad, the Ministry of Foreign Affairs has brought home 6,749 stranded Malaysians, mainly students and people in countries with high COVID-19 cases and deaths (Jaffar, 2020). They quarantined in a selected hotel that started from April 3, 2020, to prevent imported cases of COVID-19. Family members are advised not to pick their relatives from the airport as they will be taken straight to the quarantine centres (Ruzki, 2020). The government gives away RM150 and provides three meals a day, including those quarantined at five-star hotels (Ruzki \& Karim, 2020). Starting June 1, 2020, there will be no free accommodation, including citizens and noncitizens. The quarantine hotel's charge has revised in which full payment and half payment will charge to non-citizens and citizens, respectively (Muhamad, 2020).

\section{e) Shelter for homeless}

As reported by the Ministry of Federal Territories (2020a\&b), Malaysia has gathered over 500 homeless people and their families from living on various Kuala Lumpur streets and placed them in temporary shelters during the on-going movement restrictions. They include foreigners, people abandoned by their families, sick, poor, mental illness patients, drug addicts, alcoholics, and former prisoners. They have provided in shelters with essentials, mattresses, blankets, and three times meals per day. This programme's success is due to the collaboration with Kuala Lumpur City Hall staff (about 100 staff), RMP, Kuala Lumpur Welfare Department, and Malaysian Red Crescent.

A post-MCO initiative by the Ministry of Federal Territories had granted minimum wage jobs to about 300 homeless. The first batch of the homeless began to work on May 13, 2020, with three companies: Adabi Consumer Industries, Hartalega NGC, and Harumi Brands while the second batch will be working with another three companies, namely Top Glove, Tesco Malaysia, and Trendcell.

\section{Center at the Malaysia Agro Exposition Park Serdang (MAEPS)}

Incredibly, the MoH has set up a hospital in Malaysia Agro Exposition Park Serdang (MAEPS), Serdang as Malaysia's largest convention centre in four days to house the low-risk COID-19 patients if the number of positive cases continues to rise. The quarantine centre has 221 staff consisting of three medical experts, 34 medical personnel, 90 trained nurses, 21 pharmacists, eight X-ray technicians, nine medical lab technicians, nine food and dieticians, two counsellors and 36 from other categories. The centre also has a mental and psychological support team to provide emotional, psychological, and spiritual supports for the patients and staffs alike (Loheswar, 2020). Facilities for patients include beds, tables, chairs, lockers, television, lounges, WIFI access, computers, prayer room, closed-circuit television (CCTV), toilets, and baths changing rooms and rest areas. There are nurse stations, personal protective equipment (PPE), treatment/resuscitation rooms, rest areas, changing rooms, baths, meeting and seminar rooms For health personnel (Prime Minister's Office, 2020).

\section{Immigration and Deportation}

An operation by Malaysian Authorities to detent hundreds of undocumented migrants in Kuala Lumpur since May 1, 2020, intended to alleviate COVID-19 outbreaks (Razali, 2020) following infections involving them continue to be a significant contributor in this disease cases since the outbreak (Ruzki \& Parzi, 2020). First, the government has ordered that Menara City One, Kuala Lumpur, be placed under the Enhanced Movement Control Order (EMCO) after the condominium reported 17 confirmed COVID-19 cases (Bernama, 2020a). On May 1, 2020, Immigration Department and RMP have carried 
out massive raids on migrant workers and refugees in Menara City One, Malayan Mansion, and other residences in the vicinity currently under EMCO (Amnesty International, 2020).

Secondly, the Rohingya ethnic group at the Ijtimak Tabligh gathering at the Sri Petaling Mosque was uncooperative to attend the screening and most of them live in the Selayang wholesale market. The immigration department conducted a raid in that area on May 11, 2020, involving RMP, MAF, and MoH (Ramli, 2020).

\section{Economic Stimulus Packages: Everyone Counts}

To mitigate the impact of COVID-19 and the MCO, as reported by the Ministry of Finance (2020), the government has introduced the Prihatin Rakyat Economic Stimulus Package PRIHATIN that was announced on February 27, 2020. The RM250 billion package expected to ease the burden of citizens and the business community. Of the total amount, almost RM128 billion are channelled to protecting individuals, families, and communities, RM100 billion for supporting businesses, including Small and Medium Enterprises (SMEs) and RM2 billion to strengthen the economy. At the same time, the remaining RM20 billion was announced in the previous stimulus package.

The government empathizes with individuals who are financially affected following the calamity. To ease their burden, the government will provide one-off cash assistance, PRIHATIN with an allocation of RM10 billion among the beneficiaries includes:

a) Households earning $\leq$ RM4,000 per month - RM1,600

b) Households earning RM4,001 - RM8,000 per month - RM1,000

c) Single individuals earning $\leq \mathrm{RM} 2,000$ per month $-\mathrm{RM} 800$

d) Single individuals earning RM2,001 - RM4,000 per month - RM500

e) Student-RM200

The government is also concerned about vulnerable groups such as elderly citizens and children in shelters, disabled, homeless, and natives. Thus, the government with collaboration non-governmental organizations (NGOs) and relevant social entrepreneurs to provide food assistance, healthcare, and shelters with a total allocation of RM25 million. Briefly, this package could be summarized as follows:

a) Special allowance of RM600 for health and medical personnel.

b) Special allowance of RM200 to military, police, customs, immigration, fireman, civil defence, and volunteer.

c) Suspension of Skills Development Fund Corporation for six months.

d) Provide $15 \%$ discount on tourism sector electricity bill and two per cent for commercial, industrial, agricultural, and household sectors in Peninsular Malaysia.

e) Additional discounts on electricity use rates. The government and Tenaga National Berhad (national electricity agency) raised an allocation of RM530 million to provide a gradual discount of between $15 \%$ and $50 \%$ on electricity usage with a maximum limit of 600 kilowatts per month.

f) Free high-speed internet, at a rate of one gigabyte (GB) per day, until the implementation of the MCO ends.

g) 'One-off' payment to taxi drivers of RM600.

h) Deferred payment of income tax instalment to all SMEs for three months.

i) Delay in tax instalment payments to businesses affected by the tourism sector for six months.

j) Government, semi-government, and cooperative loan repayment moratorium to SMEs.

\section{Non-Citizenship Welfare}

Malaysia is home to more than two million documented migrant workers, between two and four million undocumented migrant workers, and more than 170,000 refugees. During a pandemic, successful governance requires that all residents be accounted for, regardless of their socioeconomic 
status or citizenship. These unfortunate groups have limited access to health or social welfare services and financial costs. These communities are easy prey for misinformation and fear. However, the Malaysian NGOs has toiled up this vulnerable group to ensure they are protected.

Without neglecting the immigrants, MoH, the Crisis Preparedness and Response Centre, United Nations High Commissioner for Refugees (UNHCR) in collaboration with NGOs- Mercy Malaysia, Islamic Medical Association of Malaysia and Malaysian Relief Agency have been reaching out to refugees across the country to come forward for COVID-19 screening notably Rohingya ethnic group who attended the Ijtimak Tabligh gathering. The teams provide information on COVID-19, arrange for testing if refugees present symptoms, and advise refugee communities to comply with the Government's MCO. Mercy Malaysia would ensure that their family members quarantined, and food aid would be given (Devendiran, 2020 \& Bernama, 2020b).

Transversely, the religion, race, nationality, Tzu Chi, an NGOs run by Malaysian Chinese ethnic have greatly benefited refugees in providing free medical care and food pack among the Rohingyas during the pandemic. Necessities distribution is a dominant aid carried out by various NGOs on refugees. Several NGOs focus on individual refugees such as Malaysia for Syria and Cinta Syria Malaysia for Syrian refugees. For Malaysian Humanitarian Aid and Relief, Carefugees, Tenaganita, and MyCARE Malaysia, distribution has been made to refugees and migrant workers including Rohingya, Somalia, Afghanistan, Pakistan, Syria, Yemen, Palestine, Indonesia, and Bangladesh.

Apart from economic effects, COVID-19 also impacts mental health, particularly people affected due to loss of social space, stranded at home, unemployment, financial crisis, marital issue, and supply chain shortage, leading to depression. Following these cases, Mercy Malaysia and Tenaganita have initiated an emergency hotline for refugee and migrant workers who need immediate help and psychosocial support.

\section{Conclusion}

COVID-19 pandemic has unleashed chaos in the world. Governments and organizations are scrambling to toil and contain the deadly virus from spreading further. In Malaysia, a country of 31 million people, over 6,000 have infected with COVID-19, and 100 above fatalities have reported. Despite the fact, Malaysia is going through a vast political crisis with a new leader, and several states have new governments at that dismal time. Nevertheless, it is not a hindrance for Malaysia to continue battling against COVID-19. Initially, the Malaysian Government has followed and guided the WHO and experts' procedures to prevent widespread spread.

When the case escalated on the second wave, the ruling party has built policies immediately with $\mathrm{MoH}$, RMP, and MAF involvement. Despite the political crisis, the government capable of managing the pandemic came from these agencies' contributions as a backbone. They play a vital role in the contentment of the disease through the restriction of movement. The state takes strict legal action against those who do not abide by the directives. Besides, other measures also have been implemented, such as quarantine of people returning from oversea, a shelter for homeless, set up treatment centre at the MAEPS and operation by Malaysian Authorities to detent migrants. Simultaneously, in the face of this crucial circumstance, most citizens suffer economic loss - especially the manufacturing industries, in which their operation has been halted and thus affected their income.

Meanwhile, through the implementation of PRIHATIN's package, the government is confident that the disease's spread will contain, and the citizens' well-being restore. During a pandemic, successful governance requires that all residents be accounted for, regardless of their socioeconomic status or citizenship. Without neglecting the immigrants, government and numerous NGOs have helped refugees and migrant workers in medical care, foods, and shelters. 


\section{References}

Adnan, M., Khan, S., Kazmi, A., Bashir, N., \& Siddique, R. (2020). COVID-19 infection: Origin, transmission, and characteristics of human coronaviruses. Journal of Advanced Research, 24, 91-98.

Amnesty International. (2020, May 1). Crackdown on migrants and refugees an appalling violation of human rights. Amnesty International. https://www.amnesty.my/2020/05/01/crackdown-onmigrants-and-refugees-an-appalling-violation-of-human-rights/

Bernama. (2020a, March 31). PKPD: Kes Menara City One berkait dengan kluster tabligh. Sinar Harian. https://www.sinarharian.com.my/article/76661/KHAS/Koronavirus/PKPD-Kes-MenaraCity-One-berkait-dengan-kluster-tabligh

Bernama. (2020b, March 24). Rohingya who attended tabligh gathering urged to go for screening. The Sun daily. https://www.thesundaily.my/local/rohingya-who-attended-tabligh-gatheringurged-to-go-for-screening-BX2176366

Daim, N. (2020, May 18). Muhyiddin has majority support as PM, says Agong. New Straits Times. https://www.nst.com.my/news/politics/2020/05/ 593485 /muhyiddin-has-majority-support-pmsays-agong.

Devendiran, P. (2020, April 13). UNHCR-GoM joint action to prevent, manage Covid-19 infections among refugees. UNHCR. https://www.unhcr.org/en-my/news/stories/2020/4/5e94189d4/unhcrgom-joint-action-to-prevent-manage-COVID-19-infections-among-refugees.html

Foon, W, H. (2020, February 24). Malaysia's Dr Mahathir quits as premier. The Star. https://www.thestar.com.my/news/regional/2020/02/24/ malaysias-dr-mahathir-quits-aspremier.

Jaffar, K. (2020, April 6). 6,749 Rakyat Malaysia Berjaya Dibawa Pulang Ke Tanah Air. Ministry of Foreign Affairs. https://www.kln.gov.my/web/guest/-/6-749-rakyat-malaysia-berjaya-dibawapulang-ke-tanah-air

Khor, V., Arunasalam, A., Azli, S., Khairul-asri, M. G., \& Fahmy, O. (2020). Letters to the Editor: Experience from Malaysia During the COVID-19 Movement Control Order. Urology, 00(00), $1-2$.

Loheswar, R. (2020, May 6). Health D-G: Maeps quarantine centre gives hospitals breathing space in treating Covid-19. Malay Mail. https://www.malaymail.com/news/malaysia/2020/05/06/healthd-g-maeps-quarantine-centre-gives-hospitals-breathing-space-in-treat/1863677

Malaysian National Security Council. (2020a, March 17). https://www.mkn.gov.my/web/wpcontent/uploads/sites/3/2020/03/30.-FAQ-KPDNHEP_17Mac2020.pdf.

Malaysian National Security Council. (2020b, March 18). https://www.mkn.gov.my/web/wpcontent/uploads/sites/3/2020/03/PERGERAKAN-KAWALAN-COVID19-amended-18032020UPDATED-12.12AM.pdf.

Malaysian National Security Council. (2020c, March 18). https://www.mkn.gov.my/web/wpcontent/uploads/sites/3/2020/03/FAQ-KPM.pdf.

Malaysian National Security Council. (2020d, March 20). https://www.mkn.gov.my/web/wpcontent/uploads/sites/3/2020/03/KENYATAAN-MEDIA-KDN-JIM-KAWALANPERGERAKAN-DI-PINTU-PINTU-MASUK-NEGARA-OLEH-JABATAN-IMIGRESENMALAYSIA-20032020.pdf.

Malaysian National Security Council. (2020e, March 21). https://www.mkn.gov.my/web/wpcontent/uploads/sites/3/2020/03/9.-FAQ-KPT_21Mac2020.pdf.

Malaysian National Security Council. (2020f, May 3). https://www.mkn.gov.my/web/wpcontent/uploads/sites/3/2020/05/1.-FAQ-KPM-PKPB_3-Mei-2020.pdf.

Malaysian National Security Council. (2020h, May 4). https://www.mkn.gov.my/web/wpcontent/uploads/sites/3/2020/05/8.-FAQ-KBS-PKPB_4-Mei-2020.pdf.

Malaysian National Security Council. (2020i, May 7). https://www.mkn.gov.my/web/wpcontent/uploads/sites/3/2019/08/12.-FAQ-KPT-PKPB_7-Mei-2020.pdf.

Malaysian National Security Council. May 3 (2020g, May 3). https://www.mkn.gov.my/web/wpcontent/uploads/sites/3/2020/05/3.FAQ-MOT-PKPB_3-Mei-2020.pdf.

Ministry of Federal Territories. (2020a, May 13). http://kwp.gov.my/images/beritapengumuman/2020/13052020-Kenyataan-Media-YBM-Mengenai-Penempatan-

Gelandangan.pdf 
DOI: https://doi.org/10.47405/mjssh.v6i1.620

Ministry of Federal Territories. (2020b, May 8). http://kwp.gov.my/images/beritapengumuman/2020/08052020-Kenyataan-Media-YBM---Program-Persediaan-KerjayaGelandangan.pdf

Ministry of Finance Malaysia. (2020, March 27). https://www.treasury.gov.my/pdf/BookletPRIHATIN-EN.pdf

Muhamad, H. (2020, May 20). COVID-19: No more free accommodation, hotel quarantine to be charged from June 1. Astro Awani. http://english.astroawani.com/malaysia-news/covid-19-nomore-free-accommodation-hotel-quarantine-be-charged-june-1-243732

Nadzri, M. M. N. (2018). The 14th General Election, the Fall of Barisan Nasional, and Political Development in Malaysia, 1957-2018. Journal of Current Southeast Asian Affairs, 37(3), 139171.

Prime Minister's Office. (2020, March 30). https://www.pmo.gov.my/2020/03/COVID-19-pm-visitsmaeps-low-risk-patient-quarantine-treatment-centre/

Ramli, A, M. (2020, May 11). Imigresen serbu Pasar Borong Kuala Lumpur. Sinar Harian. https://www.sinarharian.com.my/article/82986/EDISI/Selangor-KL/Imigresen-serbu-PasarBorong-Kuala-Lumpur

Razali, A, S. (2020, May 1). Penguat kuasa buru warga asing untuk sekat wabak. Berita Harian. https://www.bharian.com.my/berita/nasional/2020/05/684159/penguat-kuasa-buru-warga-asinguntuk-sekat-wabak

Ruzki, M, R. \& Karim, A, A, L. (2020, April 8). COVID-19: Kadar RM150 dipersetujui hotel diwarta pusat kuarantin.

Berita

Harian. https://www.bharian.com.my/berita/nasional/2020/04/674559/COVID-19-kadar-rm150dipersetujui-hotel-diwarta-pusat-kuarantin

Ruzki, M, R. \& Parzi, N, M. (2020, May 19). COVID-19: Warga asing penyumbang utama kes harian. Berita Harian. https://www.bharian.com.my/berita/nasional/2020/05/690717/covid-19warga-asing-penyumbang-utama-kes-harian

Ruzki, M, R. (2020, March 31). COVID-19: Rakyat Malaysia pulang dari luar negara dikuarantin. Berita Harian. https://www.bharian.com.my/berita/nasional/2020/03/671366/COVID-19-rakyatmalaysia-pulang-dari-luar-negara-dikuarantin

World Health Organization. (2020, May 11). WHO virtual press conference on COVID-19. https://www.who.int/dg/speeches/detail/who-director-general-s-opening-remarks-at-the-mediabriefing-on-covid-19---11-march-2020 